\title{
Geological Study of Tangi Mahi-Par Mountain Range along Kabul Jalalabad Road, Afghanistan
}

\author{
Hafizullah Rasouli' ${ }^{1}$, Mohammad Hasib Sarwari' ${ }^{1}$, Khairuddin Rasikh ${ }^{2}$, Said Amin Hashimi ${ }^{1}$ \\ ${ }^{1}$ Department of Geology, Geoscience Faculty, Kabul University, Kabul, Afghanistan \\ ${ }^{2}$ Department of Geology and Mining, Science Faculty, Nangarhar University, Nangarhar, Afghanistan \\ Email: hafizullah.rasouli133@gmail.com
}

How to cite this paper: Rasouli, H., Sarwari, M.H., Rasikh, K. and Hashimi, S.A. (2020) Geological Study of Tangi Mahi-Par Mountain Range along Kabul Jalalabad Road, Afghanistan. Open Journal of Geology, 10, 971-980.

https://doi.org/10.4236/ojg.2020.1010044

Received: September 1, 2020

Accepted: October 17, 2020

Published: October 20, 2020

Copyright (c) 2020 by author(s) and Scientific Research Publishing Inc. This work is licensed under the Creative Commons Attribution International License (CC BY 4.0).

http://creativecommons.org/licenses/by/4.0/

\section{Open Access}

\begin{abstract}
Tangi Mahi-par is a fault valley from previews geological period (Pleistocene) where the Kabul basin was a lake and occupied by water, and after the formation of Tangi Mahi-par fault valley, water was drained from this way. Therefore, this research is essential to elucidate the different rocks types and structures, with no or scarce previous research's in this mountainous area. The main objective of this study is to selected rock type, rocky structures and different sizes of river sediments transported by rivers discharge from the previous geological periods. There are different types of sediments, terrace remnants, rocks and geological structures which are generally consist of Limestone and Gneiss, where the limestone is likely belonging to the Thythes ocean remnants in Afghanistan and contains Ammonites fossils. In some parts volcanic breccias, it shows the old volcanic eruptions, Stalactite and stalagmite Carbonitic sediments related to limestones are also present there. In addition, there are different types of geological structures such as Anticline, Syncline, dyke, Sill, Apophysis, Graben and Horst. Unconformities and horizontal layers related to Khengal and Cottagay series passing from this area are located one by another.
\end{abstract}

\section{Keywords}

Tectonic Activities, Limestone, Gneiss, Graben, Horst

\section{Introduction}

This study evaluates the rock types of Khengal and Cottagay series in the Tangi Mahi-par at the east part of Kabul. This area is belonging to the Indian plate where the Indian plate is separated by tectonic activities from Gondawana about 140 million years ago with a speed of $20 \mathrm{~cm} /$ year toward the Asian plate and ex- 
actly this area is separated from the Indian plate in tertiary (about 90 million years ago). In this case, a movement of about 2000 miles happened at the duration of 50 million years, and with the collision of the Indian plate with the Asian plate, Himalayan Mountain formed which belongs to the Alpine orogeny [1]. Quaternary sediments are typically less than $80 \mathrm{~m}$ thick in the valleys of the area [2]. The Kabul Basin can be described as a valley-fill basin and range setting where the valleys are filled with Quaternary and Tertiary sediments and rocks [3], and the ranges are composed of uplifted crystalline and sedimentary rocks [4] [5]. The underlying Tertiary sediments have been estimated to be as much as 800 $\mathrm{m}$ thick in the Kabul city and may be more than $1000 \mathrm{~m}$ thick in some areas of the valley [6] [7]. The surrounding mountains are primarily composed of $\mathrm{Pa}$ leo-Proterozoic gneiss and Late Permian through Late Triassic sedimentary rocks [7]. The gravel and sand were deposited mainly in the river channels, describing the Lata-band Formation as Quaternary terrace sediments of middle and younger Pleistocene age overlying conglomerates. The Khengal and basement rocks are over thrust by schist mélange, which has been called the Cottagay Series in the northern Kohe-Safi range [8], and they are under thrust by mélange in Kabul River gorge. The eastern boundary of the Kabul Basin is marked by a few discontinuous, linear faults, and scarps that are displaying normal dip-slip movement [9]. The Granite of Paghman at Kabul block is belonging to Precambrian and Khengal series [10], where the Kabul block is surrounded by different faults systems which include Chamman-moqure, Sorobi, and Mahi-par faults [11] [12]. The Kabul Basin is a part of the Kabul block which is tectonically active in the transpressional plate-boundary region of Afghanistan [13] [14]. The inter-basin ridges [15] [16], composed of metamorphic core-complex rocks, are Paleoproterozoic gneiss [17]. The age of sediments related to Khengal series is started from Jurassic [18], and it's belonging to the part of Thythes Ocean in Afghanistan [19].

\section{Geological Setting}

The Tangi Mahi-par and Naghlu are in the east of Kabul, on the Hindu Kush Mountain range in Afghanistan, where the geological characteristics and locations are shown in (Figure 1). The study area covers an area of $3.5 \mathrm{~km}^{2}$ with a maximum elevation of $2500 \mathrm{~m}$ above sea level in Poly-charkhy mountain range and minimum elevation is $800 \mathrm{~m}$ located in Tangi Mahi-par valley based [10]. The Kabul, Logar and Paghman rivers are gathering to flow between this valley, and the sediments of these rivers make different terraces along the valley [10], as studied in this research.

\section{Horst and Graben}

In Tangi Mahi-par we can see Graben where the young layers of limestone came down on old gneisses and caused the formation of Graben. The old layers are belonging to Kabul crystalline and it is belonging to Khengal series (Figure 2). The 


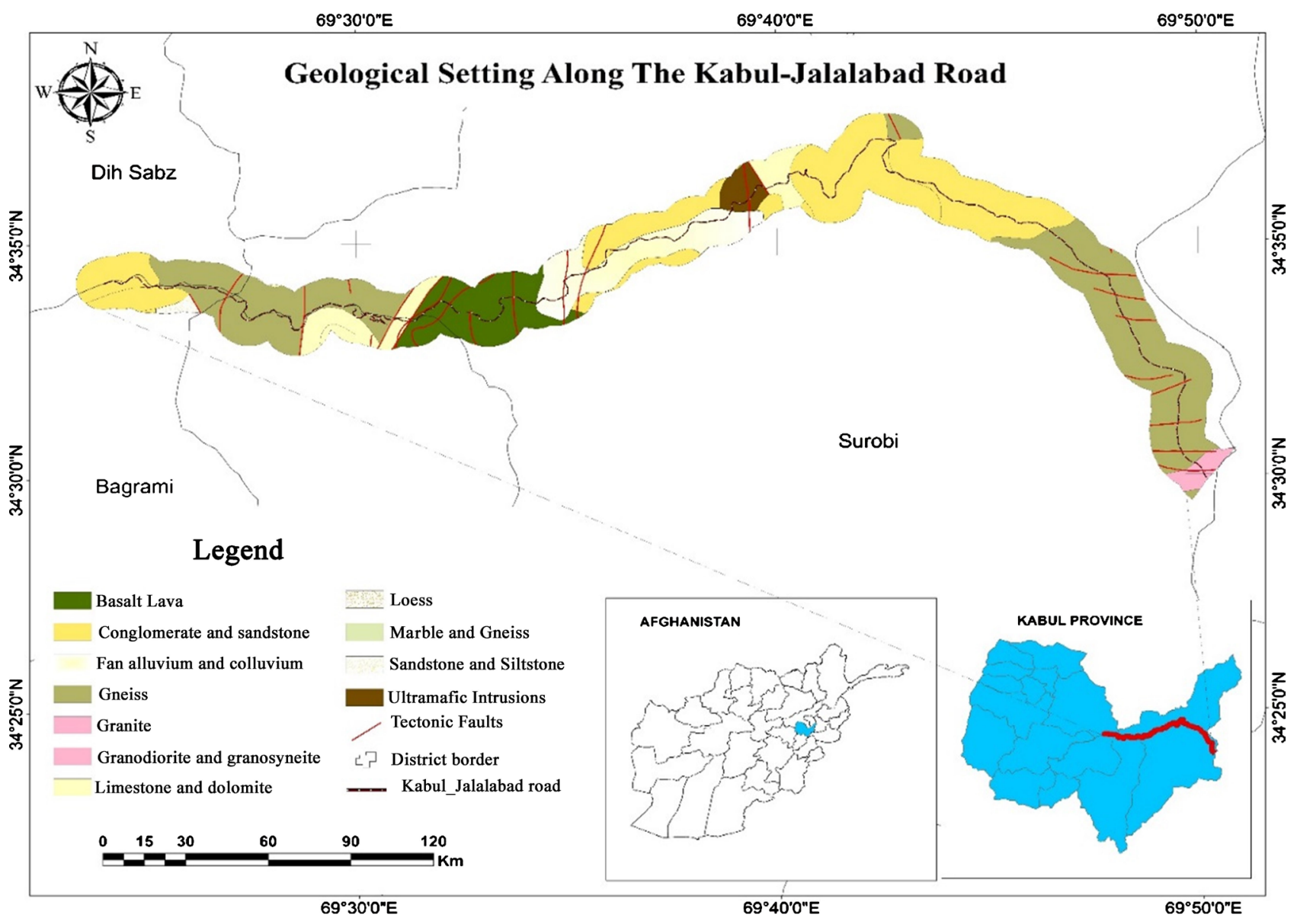

Figure 1. Location map and Geological setting of the Kabul - Jalalabad road at Tangi Mahi-Par, Kabul, Afghanistan.

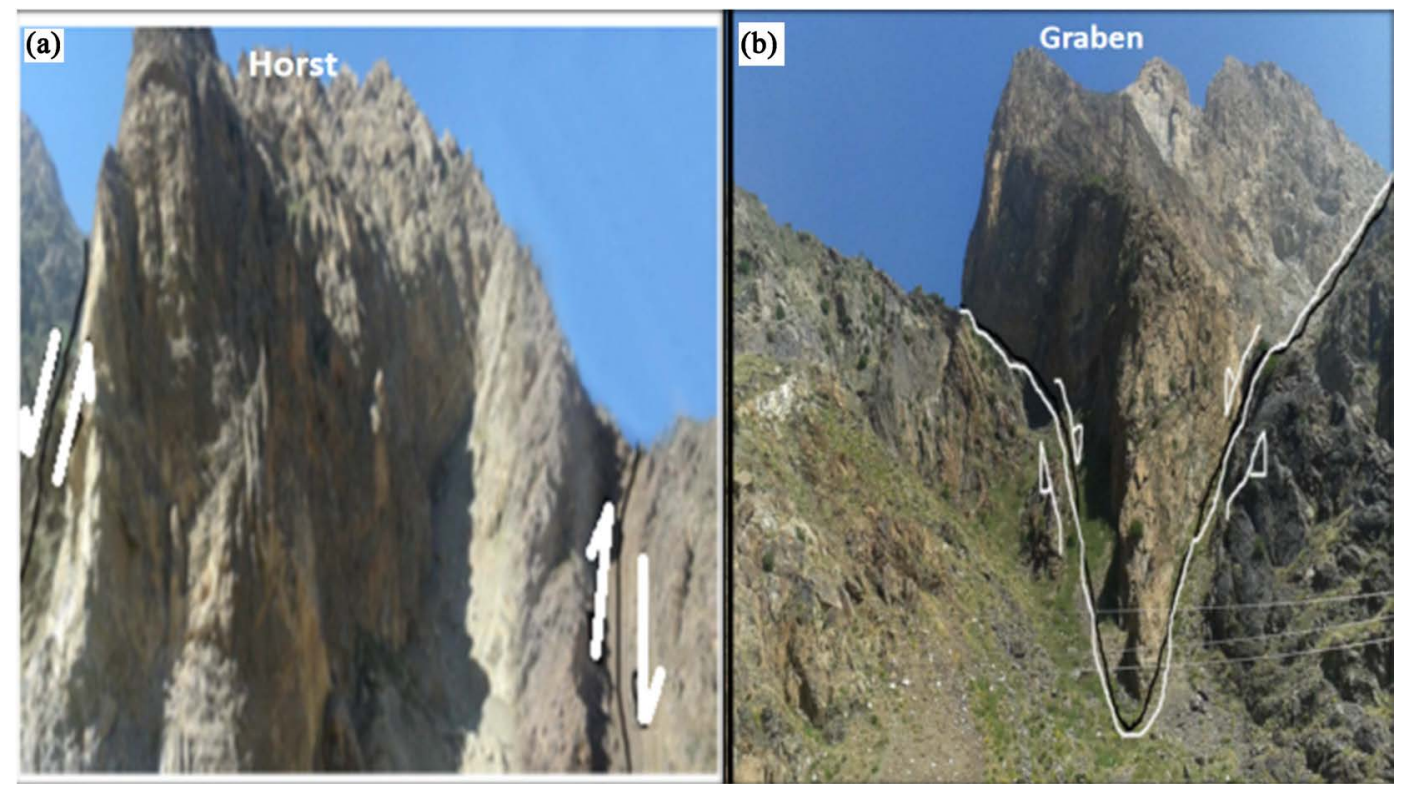

Figure 2. Graben in metamorphic rocks and Limestone at Tangi Mahi-par, Kabul, Afghanistan.

Gneisses is likely to have Precambrian age [18], and it is mainly consisting of Quartz and Amphiboles, also the sedimentary rock (Arkos) can be seen in the 
area and it is likely to be formed from the weathering and erosion of Gneisses. In the crystalline which is belonging to Precambrian the main reason for graben formation is the extension made in the area. The faults which are caused by the formation of Horst and Graben belong to cretaceous, and two types of layers can be defined in the mentioned host rocks, where the thin rock layers belonging to folds and another with more thickness is belonging to layering structures.

\section{Fault Surface}

A normal fault with fault surface signs like shears, slicken side, fault breccia and fault millonite as shown in Figure 3(a) and Figure 3(b) are present in the area, where from shear plain it can be found that the normal fault is Graben type and it is formed due to the extension. The quartz dike and types of schistosities also can be observed in the fault surface. Generally, this mountain series is extended from northwest to southeast and the present faults have an angel of $35^{\circ}-45^{\circ}$ where its surface is extended from northwest to southeast. In the formed graben and horst, the old rocks are gneisses and the newly formed rock is limestone.

\section{Layers, Strike and Dip}

The Strike and dip between layers are different, generally, the strike of layers are SW and NE, and due to complex tectonic activities, the dip angles differ to a large extent $\left(10^{\circ}, 49^{\circ}, 45^{\circ}, 30^{\circ}, 40^{\circ}, 35^{\circ}, 65^{\circ}, 67^{\circ}\right.$ and $\left.75^{\circ}\right)$ (Figure 4 ).

\section{Anticline, Syncline and Folds}

On the other side of Graben, anticline and syncline structures are visible, where Anticline and syncline are consisting of some special folds at their limbs which caused the formation of anticlinorium and synclinorium. The folds in the area
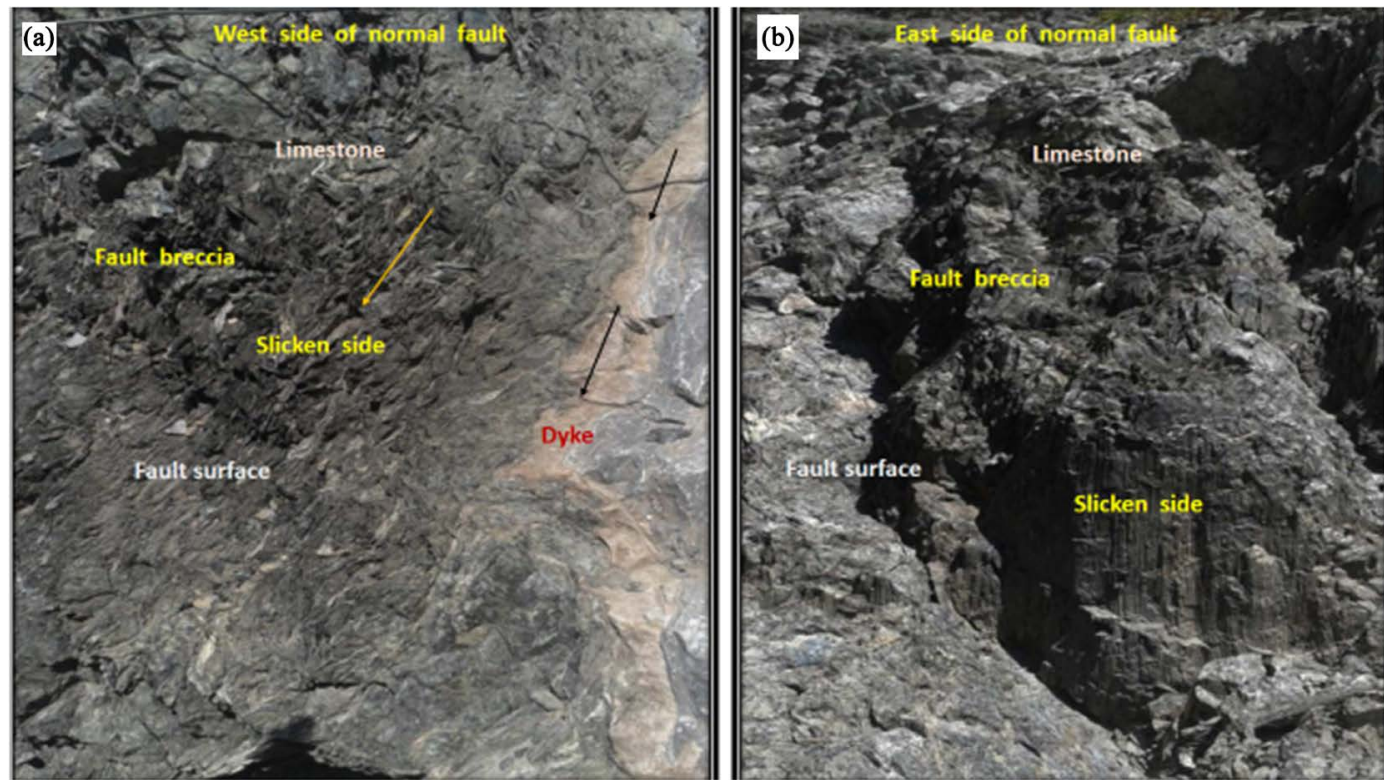

Figure 3. Shows normal fault surface and its different fault surface structures at the Tangi Mahi-par rocks. 
involve both symmetrical and asymmetrical folds and with considering the folds axial plain in Tangi Mahi-par mountain range, other types of folds like cylindrical, non-cylindrical, and vergent can be seen which are formed due to complex tectonic activities in the area (Figure 5).

According to tectonic activities through geological time, in this mountain range, different types of fold element signs like hinge line, hinge zone, hinge point, hinge trace, fold axis, inflection point, inflection line, limb, inter limb angle were also found [16].

\section{Terraces}

The Anar-Bagh village terrace belonging to the tertiary period shows that there was a river bed that is formed after about $10 \mathrm{~m}$ down cutting. In this terrace different types of gravel formations (boulder, cobble, pebble, and granule), sand and silt can be seen, where from the size of mentioned sediments the velocity of river flow in previews geological periods can be judged (Figure 6(a)). At the Tagab side of Sorobi limonite was found which is eroded from siderite along Salang river and transported by the mentioned river to the area. On the other side river terraces are present which are made from angular unconformities, and

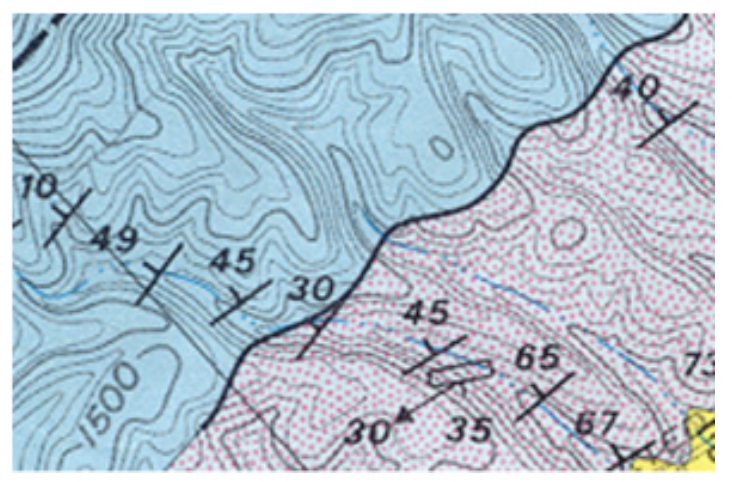

Figure 4. Different measurements of dip angles in Tangi Mahi-par rocks.

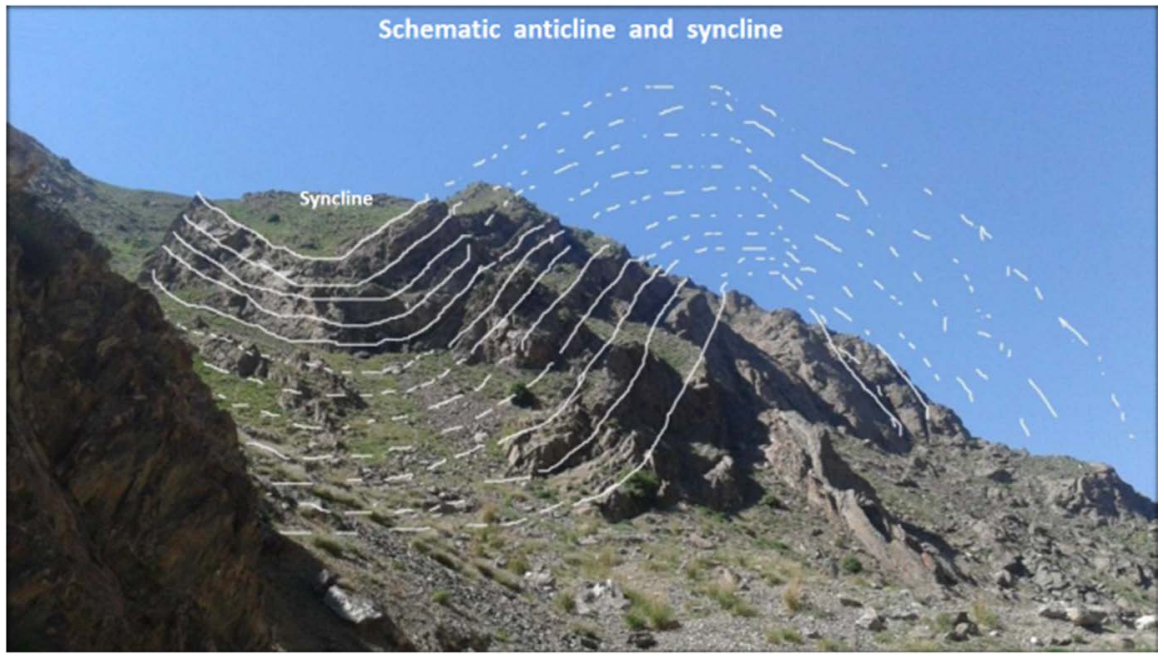

Figure 5. Anticline and syncline in Tangi Mahi-par gneiss. 


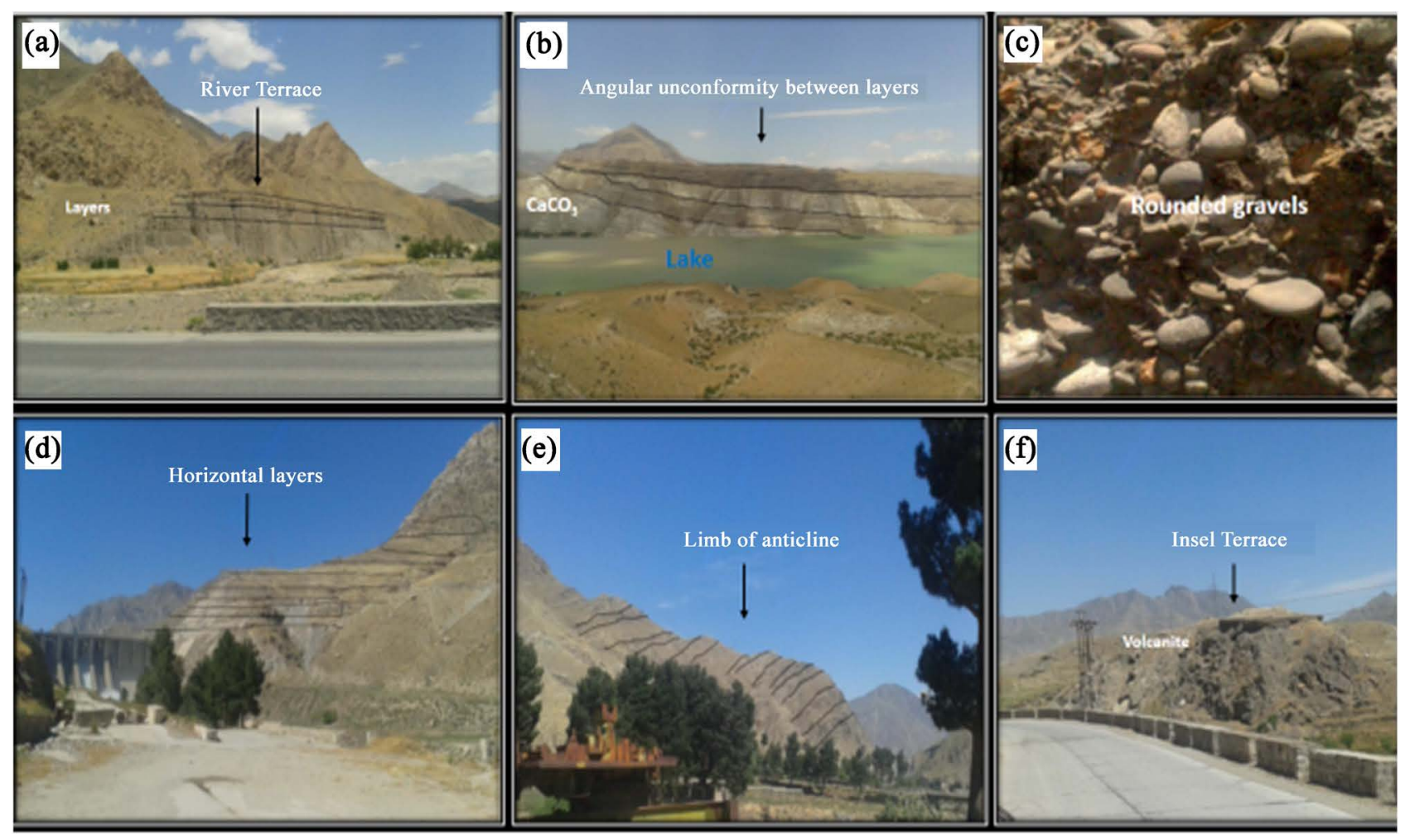

Figure 6. Showing river terraces (a), unconformity (b), gravel formation (c), horizontal layers (d), terraces in the limb of anticline (e), and in seal terrace (f).

between the layers is consisting of siderite and $\mathrm{CaCo}_{3}$ (Figure 6(b)). On the east side about $2 \mathrm{~km}$ down there are sediments from the cretaceous period, which is gravel formation and different types of rounded gravels with the matrix material of medium sand and iron oxides can be found. Among this gravel, formation rounded and flat rounded gravel can be seen where their shapes are belonging to the river stream and velocity (Figure 6(c)).

On the east side of Naghlu dam, the layers are horizontal, where the reservoir water has percolated between the layer (Figure 6(d)). At the down, southeast side terraces are formed in an anticline limb and its rock is gneiss, where it strikes SE to NW with the dip angle of $35^{\circ}$ to $45^{\circ}$ (Figure 6(e)). Near to the main road at the east side of the river, there is in seal terrace, which is made from volcanic breccia and the limonite with iron oxides can be seen in it too (Figure 6(f)).

\section{Veins and Carbonates}

From the site visit along the Tagab road, different types of viens such as sill, dyke and apophysis were seen between gneisses. The gneisses are belonging to the late Precambrian (protozoic) [17] and Kabul crystalline (Figure 7(a)). At the Tangi Mahi-par near the Kabul Jalal Abad road, the carbonate sediments were found in the caves, which is due to surface water infiltration and formed different types of Carbonitic features such as Stalactite, Stalagmite, and columns (Figure 7(b)). 


\section{Volcanic Breccia}

In the study area, volcanites and volcanic breccia has been found which are likely belonging to volcanic eruption around the area at previews geological periods, and it is mainly formed due to sedimentation and action of the diageneses process on ascended particles from volcanic eruptions, where eventually caused the formation of volcanic breccias (Figure 8).

\section{Samples and Methods}

The following methods and procedures were undertaken in this study: Direct field investigation and sample collection from the study area with the detailed studies of available rocks, sediments and tectonic structures. Different samples were collected from the underground working sites and the ground surface of Sorobi terraces and its deposits. Studies were undertaken on quartz veins available in Gneisses, and the microscopic observations on thin sections made from

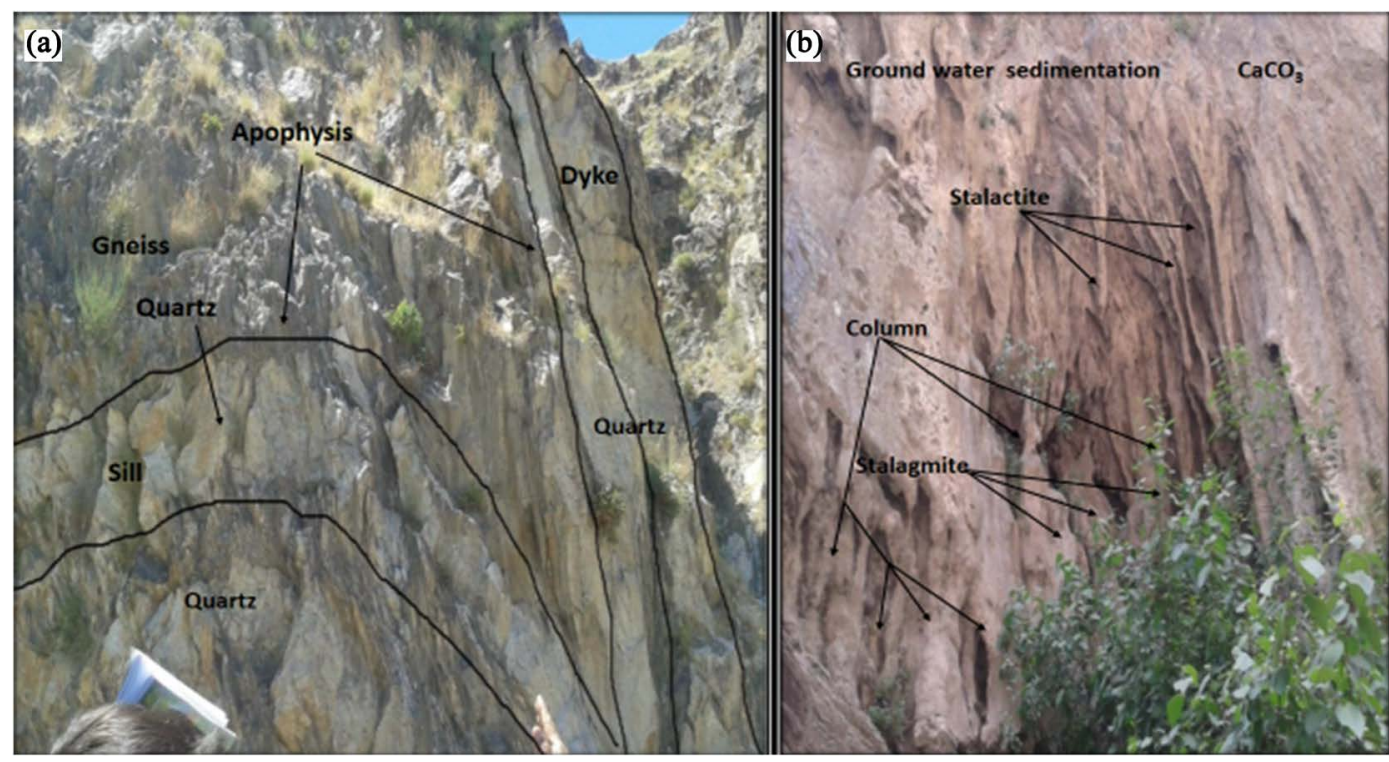

Figure 7. Showing different types of veins $(\mathrm{m})$ and Carbonitic sedimentary features at the caves of Tangi Mahi-par (n).

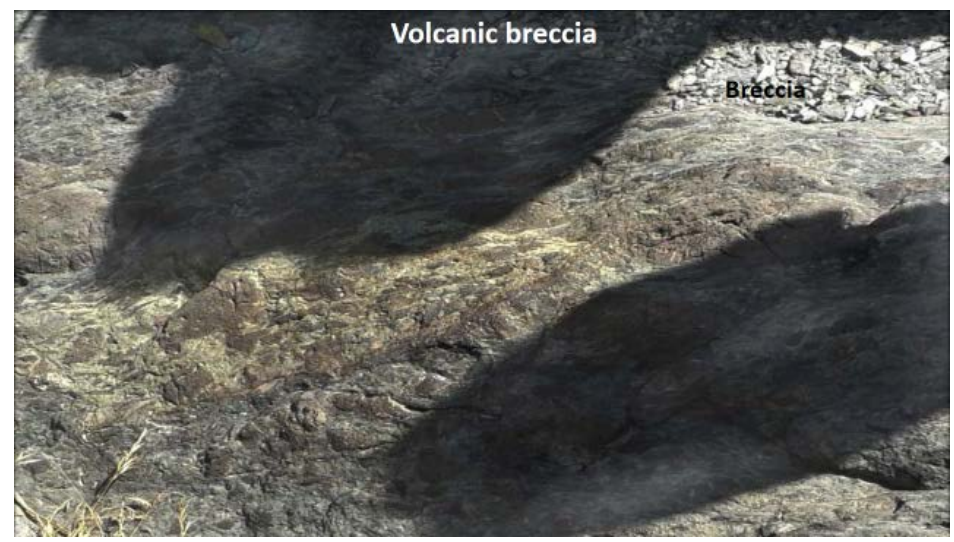

Figure 8. Volcanic breccia at the Tangi Mahi-par mountain range. 
rocks of study area were conducted. A polarized microscope (Nikon Eclips E600 POL equipped with an Ad- van Can-U2II camera) was used for microscopic observation of thin sections, and the structural analysis is based on visual observations in different locations of the study area (Tangi Mahi-par and Sorobi).

\section{Discussions and Conclusions}

This research aimed to study the geology and geological structures of Tangi Mahi-par and Sorobi along Kabul Jalalabad road. The main rock types in the study area were Gneisses and limestone, where the gneisses are belonging to Cottagey series with the age of Proterozoic and the limestones are belonging to the Khengal series. The sedimentary rock (Arkoz) was also found in the area which is likely formed due to erosion of available gneisses in the area. The quartz veins (such as dykes and sills) with trace amounts of amphiboles were also available along the study area. Main geological structures seen were horsts and grabens, where it was consisting of old age gneisses and young age limestones, and the main reason for the formation of above structures can be the extension and compression of faults (normal faults) belonging to the Cretaceous. The horsts and grabens can be seen in two types of layers, which are thick layers and thin layers among limestones and gneisses, where the thick layers are the main layers and the thin layers are folded ones. The signs of fault surface (e.g. shears, slicken side, fault breccia and millonite) can be seen clearly in various locations around mentioned structures, where from the observation of shear plain and movement of masses it was found that normal faulting (graben type) has occurred. The quartz dyke and different types of schistosity can be seen in the fault surface, and the fault surface mainly strikes from NW to SE with the dip angle between $35^{\circ}$ $45^{\circ}$, however, due to the occurrence of complex tectonic activities the dip angle differs widely $\left(10^{\circ}, 49^{\circ}, 45^{\circ}, 30^{\circ}, 40^{\circ}, 35^{\circ}, 65^{\circ}, 67^{\circ}\right.$ and $\left.75^{\circ}\right)$.

Anticline and Syncline structures also can be seen at the sides of Graben and Horst, wherein the limbs of available anticline and syncline some special folds are available which caused the formation of anticlinorium and synclinorium. By considering the fold axial plain, different types of symmetrical and asymmetrical folds also can be found, where between these folds are consisting of normal, vergent, cylindrical and non-cylindrical folds. During this research, different types of fold elements are also found, which shows the occurrence of complex tectonic activities in the area at previews geological periods, where the different elements include hinge line, hinge zone, hinge point, hinge trace, fold axis, inflection point, inflection line limb, etc. The Anar-Bagh village terrace belonging to Tertiary is in the study area, where the terraces are formed due to the down cutting of the river bed up to about $10 \mathrm{~m}$. These terraces are consisting of different type of gravel formations (such as boulder, cobble, pebble, and granule), sand and silt, where the size of sedimentary formations differs in different areas and it is because of river flow velocity at previous geological periods and at different locations. At the Tagab side of Sorobi Limonite have been found, which is 
likely to be eroded from available Siderites along Salang river and transported by Salang river as well. Terraces at the Tagab side formed angular unconformities where between them is consisting of siderite and $\mathrm{CaCO}_{3}$. About $2 \mathrm{~km}$ to the east side of Sorobi gravel formations from Cretaceous are available, which are consisting of different types of rounded and flat gravels and the matrix material is consisting of medium sand and Iron oxides.

An in-seal terrace has been found in the area as well, which is made from volcanic breccia where iron oxides can be found in it as well. The volcanites and volcanic breccias are likely belonging to the volcanic eruptions of the previews geological periods around the area, and are formed after undertaking the diageneses action. Carbonitic sediments at the caves were also found at Tangi Mahi-par along Kabul Jalal Abad road which are formed by surface water infiltration and caused the formation of different Carbonitic features such as Stalactite, Stalagmite and columns.

\section{Acknowledgements}

We would like to express our warm gratitude to anonymous referees for their valuable comments, and we extend our thanks to the faculty members who helped us put this paper together.

\section{Conflicts of Interest}

The authors declare no conflicts of interest regarding the publication of this paper.

\section{References}

[1] Barley, M.E., Pickard, A.L., Zaw, K., Rak, P. and Doyle, M.G. (2003) Jurassic to Miocene Magmatism and Metamorphism in the Mogok Metamorphic Belt and the India-Eurasia Collision in Myanmar. Tectonics, 22, 1019. https://doi.org/10.1029/2002TC001398

[2] Böckh, E.G. (1971) Report on the Groundwater Resources of the City of Kabul, Report for Bundesanstalt für Geowissenschaften und Rohstoffe BGR File Number 0021016 .

[3] Bohannon, R.G. and Turner, K.J. (2007) Geologic Map of Quadrangles 3468, Chak Wardak-Syahgard (509) and Kabul (510) Quadrangles, Afghanistan: U.S. Geological Survey Open File Report 2005-1107-A. https://doi.org/10.3133/ofr20051107A

[4] Broshears, R.E., Akbari Chornack, M.P., Mueller, D.K. and Ruddy, B.C. (2005) International Groundwater Resources in the Kabul Basin, Afghanistan: U.S. Geological Survey Scientific Investigation Report 2005-5090.

https://doi.org/10.3133/sir20055090

[5] Cubitt, J.M., England, W.A. and Larter, S.R. (2004) Understanding Petroleum Reservoirs-Toward and Integrated Reservoir Engineering and Geochemical Approach. The Geological Society London, London, 495 p.

[6] Nichol, G. (2009) Sedimentology and Stratigraphy. Wiley-Blackwell, Hoboken, New Jersey, $410 \mathrm{p}$.

[7] Houben, G. and Tunnermeier, T. (2005) Hydrogeology of the Kabul Basin, Part1: 
Geology, Aquifer Characteristics, Climate and Hydrology. Fadral Institute for Geosciences and Natural Resources (BGR), Hannover, Germany, 45.

[8] Japan International Cooperation Agency (JICA) (2007) The Study on Ground Water Resources Potential in Kabul Basin in the Islamic Republic of Afghanistan: 3rd Joint Technical Committee, Sanyu Consultants, Inc., Kabul, Afghanistan.

[9] Ruleman, C.A., Crone, A.J., Machette, M.N., Haller, K.M. and Rukstales, K.S. (2007) Map and Database of Probable and Possible Quaternary Faults in Afghanistan: U.S. Geological Survey Open File Report 2007-1103, 39 p. https://doi.org/10.3133/ofr20071103

[10] Tünnemeier, T., Houben, G. and Niard, N. (2003) Hydrogeology of the Kabul Basin Part III: Modeling Approach, Conceptual and Numerical Groundwater Models. Federal Institute for Geosciences and Natural Resources (BGR), Hannover, 15-50.

[11] Thu, K. and Zaw, K. (2017) Gem Deposits of Myanmar. In: Barber, A.J., Zaw, K. and Crow, M.J., Eds., Myanmar. Geology, Resources and Tectonics, Vol. 48, the Geological Society of London, London, 497-529. https://doi.org/10.1144/M48.23

[12] Vearncombe, J.R. (1993) Quartz Vein Morphology and Implications for Formation Depth and Classification of Archaean Gold-Vein Deposits. Ore Geology Reviews, 8 , 407-424. https://doi.org/10.1016/0169-1368(93)90036-X

[13] Win, M.M., Enami, M. and Kato, T. (2016) Metamorphic Conditions and CHIME Monazite Ages of Late Eocene to Late Oligocene High-Temperature Mogok Metamorphic Rocks in Central Myanmar. Journal of Asian Earth Sciences, 117, 304-316. https://doi.org/10.1016/j.jseaes.2015.11.023

[14] Wheeler, R.L., Bufe, C.G., Johnson, M.L. and Dart, R.L. (2005) Seismotectonics Map of Afghanistan, with Annotated Bibliography: U.S. Geological Survey Open File Report 2005-1264. https://doi.org/10.3133/ofr20051264

[15] Yonemura, K., Osanai, Y., Nakano, N., Adachi, T., Charusiri, P. and Zaw, T.N. (2013) EPMA U-Th-Pb Monazite Dating of Metamorphic Rocks from the Mogok Metamorphic Belt, Central Myanmar. Journal of Mineralogical and Petrological Sciences, 108, 184-188.

[16] Zaw, K., Barbar, A.J. and Crow, M.J. (2017) Overview of Mineralization Styles and Tectonic-Metallogenic Setting in Myanmar. In: Barber, A.J., Zaw, K. and Crow, M.J., Eds., Myanmar. Geology, Resources and Tectonics, Vol. 48, The Geological Society of London, London, 531-556. https://doi.org/10.1144/M48.24

[17] Zaw, K., Sutherland, L., Yui, T.F., Meffre, S. and Thu, K. (2015) Vanadium-Rich Ruby and Sapphire within Mogok Gemfield, Myanmar: Implications for Gem Color and Genesis. Mineralium Deposita, 50, 25-39. https://doi.org/10.1007/s00126-014-0545-0

[18] Zaw, K. (1990) Geological, Petrological and Geochemical Characteristics of Granit oid Rocks in Burma: With Special Reference to the Associated W-Sn Mineraliza tion and Their Tectonic Setting. Journal of Southeast Asian Earth Sciences, 4, 293-335. https://doi.org/10.1016/0743-9547(90)90004-W

[19] Zhang, J., Xiao, W., Windley, B.F., Wakabayashi, J., Cai, F., Sein, K., Wu, H. and Naing, S. (2018) Multiple Alternating Forearc- and Backarc-Ward Migration of Magmatism in the Indo-Myanmar Orogenic Belt Since the Jurassic: Documentation of the Orogenic Architecture of Eastern Neotethys in SE Asia. Earth-Science Reviews, 185, 704-731. https://doi.org/10.1016/j.earscirev.2018.07.009 